\title{
Universiteit
}

Leiden

The Netherlands

\section{Scenarios for a $2^{\circ} \mathrm{C}$ world: a trade-linked input-output model with high} sector detail

Koning, A. de; Huppes, G.; Deetman, S.P.; Tukker A.

\section{Citation}

Koning, A. de, Huppes, G., \& Deetman, S. P. (2016). Scenarios for a $2{ }^{\circ} \mathrm{C}$ world: a trade-linked input-output model with high sector detail. Climate Policy, 16(3), 301-317.

doi:10.1080/14693062.2014.999224

Version: $\quad$ Publisher's Version

License: $\quad$ Licensed under Article 25fa Copyright Act/Law (Amendment Taverne)

Downloaded from: https://hdl.handle.net/1887/3199232

Note: To cite this publication please use the final published version (if applicable). 


\section{Climate Policy

\section{Scenarios for a $2{ }^{\circ} \mathrm{C}$ world: a trade-linked input-output model with high sector detail}

\section{Arjan De Koning, Gjalt Huppes, Sebastiaan Deetman \& Arnold Tukker}

To cite this article: Arjan De Koning, Gjalt Huppes, Sebastiaan Deetman \& Arnold Tukker (2016) Scenarios for a $2{ }^{\circ} \mathrm{C}$ world: a trade-linked input-output model with high sector detail, Climate Policy, 16:3, 301-317, DOI: 10.1080/14693062.2014.999224

To link to this article: https://doi.org/10.1080/14693062.2014.999224

\section{Published online: 09 Feb 2015.}

Submit your article to this journal $\pi$

Шll Article views: 2314

Q View related articles ๘

View Crossmark data

Citing articles: 10 View citing articles 주다. 


\title{
Scenarios for a 2 C world: a trade-linked input-output model with high sector detail
}

\author{
ARJAN DE KONING*, GJALT HUPPES, SEBASTIAAN DEETMAN, ARNOLD TUKKER \\ Institute of Environmental Sciences (CML), Faculty of Science, Leiden University, Leiden, The Netherlands
}

\begin{abstract}
In this study a scenario model is used to examine if foreseen technological developments are capable of reducing $\mathrm{CO}_{2}$ emissions in 2050 to a level consistent with United Nations Framework Convention on Climate Change (UNFCCC) agreements, which aim at maximizing the temperature rise to $2{ }^{\circ} \mathrm{C}$ compared to pre-industrial levels. The model is based on a detailed global environmentally extended supply-use table (EE SUT) for the year 2000, called EXIOBASE. This global EE SUT allows calculating how the final demand in each region drives activities in production sectors, and hence related $\mathrm{CO}_{2}$ emissions, in each region. Using this SUT framework, three scenarios have been constructed for the year 2050. The first is a business-as-usual scenario (BAU), which takes into account population, economic growth, and efficiency improvements. The second is a techno-scenario (TS), adding feasible and probable climate mitigation technologies to the BAU scenario. The third is the towards-2-degrees scenario (2DS), with a demand shift or growth reduction scenario added to the TS to create a $2{ }^{\circ} \mathrm{C}$ scenario. The emission results of the three scenarios are roughly in line with outcomes of typical scenarios from integrated assessment models. Our approach indicates that the $2{ }^{\circ} \mathrm{C}$ target seems difficult to reach with advanced $\mathrm{CO}_{2}$ emission reduction technologies alone.
\end{abstract}

\section{Policy relevance}

The overall outlook in this scenario study is not optimistic. We show that $\mathrm{CO}_{2}$ emissions from steel and cement production and air and sea transport will become dominant in 2050. They are difficult to reduce further. Using biofuels in air and sea transport will probably be problematic due to the fact that agricultural production largely will be needed to feed a rising global population and biofuel use for electricity production grows substantially in 2050. It seems that a more pervasive pressure towards emission reduction is required, also influencing the basic fabric of society in terms of types and volumes of energy use, materials use, and transport. Reducing envisaged growth levels, hence reducing global gross domestic product (GDP) per capita, might be one final contribution needed for moving to the $2{ }^{\circ} \mathrm{C}$ target, but is not on political agendas now.

Keywords: scenario; supply-use tables; technology development

\section{Introduction}

Limiting temperature rise to $2{ }^{\circ} \mathrm{C}$ compared to pre-industrial levels is broadly seen to be necessary to avoid risks of climate change. It is the stated goal of United Nations Framework Convention on Climate Change (UNFCCC) negotiations (UNFCCC, 2011). To remain within this domain, GHG emissions are to be reduced substantially, while economic growth continues, especially in developing countries. Several modelling approaches and scenarios have been developed to give insights into how we may reach this climate stabilization goal. The scenarios in line with climate stabilization

*Corresponding author. E-mail: koning@cml.leidenuniv.nl 
limit climate forcing to $2.6 \mathrm{~W} / \mathrm{m}^{2}$ in 2100 (see van Vuuren et al., 2011 and the Intergovernmental Panel on Climate Change (IPCC) - Working Group III final draft report for a survey; IPCC, 2014). The emission pathways towards 2100 of different scenarios may differ in the speed of emissions reduction. However, substantial emissions reductions should already be realized by 2050 in order to realistically remain within the $2{ }^{\circ} \mathrm{C}$ rise domain. The IPCC (2014) RCP2.6 scenario reduces $\mathrm{CO}_{2}$ emissions to around $11 \mathrm{Gt}$ in 2050, which is roughly a 50\% reduction relative to 1990 levels, or a $60 \%$ reduction relative to 2000 , the base year for our model. The goal of this article is to see how such a reduction in global $\mathrm{CO}_{2}$ emissions from industry and fossil fuel might be realized by 2050, by assuming the introduction of emissions-reducing technologies and changes in patterns of final demand, against a background of economic growth.

The scenario model developed is based on global supply-use tables (SUTs) with high sector detail known as EXIOBASE - discerning four regions in the world. In a supply-use framework, the supply table contains the supply of products by industry sectors and the use table describes the use of products by industry and by consumers (Stone, 1961). Products produced by industries are either used as intermediates by other industries or are used by final consumers. The SUTs used in this study include information on the emissions of $\mathrm{CO}_{2}, \mathrm{CH}_{4}$, and $\mathrm{N}_{2} \mathrm{O}$ as so-called 'environmental extensions' for every industry sector. The SUTs therefore provide a complete picture of the structure and in particular the relations within an economy, expressing the flow of products between industries and final uses in monetary terms. This allows the calculation of how final uses drive production - and hence emissions - in specific industries in specific regions (e.g. Miller \& Blair, 2009). The SUTs also give a description of the technology used in every industry sector, in the form of monetary inputs and outputs, plus the emissions associated with that technology (Duchin, 1998). By systematically manipulating the SUTs exogenously, they can reflect changes in technologies, final demand, and the economic activity part of the future scenario assumptions. Scenario assumptions lead to adjustments of these monetary inputs and outputs of industry sectors and their emissions, and ultimately to a new set of SUTs. The new set of SUTs can then be used again to calculate GHG emissions of economy-wide production and consumption.

Adapting monetary SUTs to examine the effects of techno-economic changes is nothing new. For instance, Cantono, Heijungs, and Kleijn (2008) adapted an input-output table (IOT) to examine the environmental effects of introducing hydrogen and fuel cell buses into the European economic system. Tukker et al. (2011) showed how dietary changes lead to structural changes in the European meat production sector and therefore their effects on the environment. SUTs and IOTs are also routinely adapted to make an estimate of a new year based on the SUT of a previous year, forcing the SUT to reflect some key economic indicators of the new year (see, for instance, chapter 7 in Lahr \& De Mesnard, 2004; Miller \& Blair, 2009). The novelty of our approach is the combination of scale, technical detail, and systematic approach to implementing techno-socio-economic scenarios in SUTs. All sectors in all regions, their interrelations and emission coefficients, will be changed, and these changes are applied using a systematic approach implemented in a set of scripts that allows for easy analysis of different scenarios.

The scenario model used for this purpose in this research deviates substantially from the integrated assessment and (partial) optimization models often used to investigate scenarios for the mitigation of climate change. Our scenario model has no endogenous dynamic relations like climate feedback mechanisms, no investment functions, no optimizations, and no learning curves. As far as is desired, such 
factors need to be defined exogenously. A major strength of our approach of implementing scenarios in a supply-use framework is the explicit introduction of new technologies with specific input, output, and emission coefficients, and the inherent inclusion of chain effects at a level of detail that does not exist in general equilibrium models. If, for instance, the supply of electricity by coal power plants is reduced in a scenario by a switch to other technologies, the supply by coal mines will also be reduced accordingly, including all related activities and emissions. All specifications of emissionsreducing technologies are based on options as specified in the literature as feasible or probable. This makes assumptions regarding technical change transparent and the interpretation of the results straightforward.

The central question in this research is whether a feasible and probable technology development until 2050 alone can reduce $\mathrm{CO}_{2}$ emissions to a level consistent with a less than $2{ }^{\circ} \mathrm{C}$ temperature increase above pre-industrial levels under a moderate population and economic development scenario and, if not, whether additional demand-side changes might reduce $\mathrm{CO}_{2}$ emission to desired levels.

This article focuses on $\mathrm{CO}_{2}$ only, because its technical emissions-reduction measures are better specified, and policies targeted at $\mathrm{CO}_{2}$ emissions seem more feasible than those for the largely difficult to measure and regulate emissions of other GHGs, most notably $\mathrm{CH}_{4}$ and $\mathrm{N}_{2} \mathrm{O}$ from land use. Furthermore, indirect land-use change and related emissions are not included. It is probably optimistic to assume that the emissions of such non- $\mathrm{CO}_{2}$ GHGs could be reduced as easily as $\mathrm{CO}_{2}$ emissions. Land use as a resource for food, feed, and bioenergy production is included in the model, but for this article it will only be considered as a limit on the contribution of bioenergy.

\section{Data and method}

In the following, an overview is given of the starting data for the scenarios, the scenario assumptions, and the model framework in which data and scenario assumptions are used to implement the scenarios.

\subsection{SUTs}

The EXIOBASE SUTs form the basis for specifying the scenarios. This world model distinguishes 129 sectors in 44 trade-linked countries and regions, including the individual EU27 countries (Tukker et al., 2013). In EXIOBASE, the national SUTs have been trade-linked. This means that all sectors in each country/region are linked to the supplying and using sectors in all other countries and regions. The trade linkages are created by combining data from national SUTs and trade data. Because these supply-use data and trade data will contain errors, the trade data are adapted to fit the supply-use data. A biproportional matrix balancing method, the so-called GRAS method (Junius \& Oosterhaven, 2003), is used to adapt the trade data so that consistency between supply-use data and trade data is achieved (Bouwmeester, 2014) with minimal adjustment to the data.

The EXIOBASE data for the year 2000 are some of the most detailed data publicly available at present. A newer version of EXIOBASE for 2007 has recently been completed, but these data are not yet publicly available (Tukker et al., 2014). For the purpose of this study the data from EXIOBASE have been aggregated into four global regions: the $\mathrm{EU}^{1}$, other high-income countries such as the US and Japan (HI), newly developing countries such as the Brazil, Russia, India, China countries BRICs (BX), and the 'rest of the world', including most African ${ }^{2}$ and Middle Eastern countries (RoW). These regions are 
treated as internally homogeneous. Choosing to perform the modelling on this four-region aggregate level and at the 129-industry-sector level has implications for the results, as will be discussed.

The EXIOBASE emission data cover the major GHGs $\left(\mathrm{CO}_{2}, \mathrm{CH}_{4}\right.$, and $\left.\mathrm{N}_{2} \mathrm{O}\right)$ as well as non-GHG emissions, and all scenarios relate to the four world regions.

\subsection{Scenarios}

Three scenarios were developed. The starting point is the world as described in 2000 in EXIOBASE, stepwise transformed into possible worlds in 2050.

\subsubsection{Business-as-usual}

The BAU scenario assumes no specific additional climate policies. However, it follows trends in energy efficiency improvement and expectations for economic growth until 2050. Population growth, general efficiency improvements, and productivity growth together lead to a more or less autonomous economic growth, already influenced by policies and other mechanisms. These general developments have been implemented in the SUTs in the following way. The trends in general efficiency improvement (influenced by current climate policies) of the last decade have been extrapolated, looking in detail at country-specific developments of the 30 most energy-consuming sectors, as derived from the World Input-Output Database (WIOD) database (Timmer, 2012). These trends are not substantial in sectors such as agriculture for developed countries (roughly 1\% efficiency improvement over the 50-year scenario period), but are much higher for some sectors in high-growth developing countries (up to $36 \%$ efficiency improvement over the 50-year scenario period, e.g. for agriculture and food industries). Efficiency improvements already lead to substantial economic growth, as can be calculated from our model. Gross domestic product (GDP) growth per region is further scaled up to meet Organisation for Economic Co-operation and Development (OECD) prospects (OECD, 2012a; 2012b) for economic growth. Figure 1 shows an overview of GDP and population development in the scenarios.

In our scenario there is no shift in developed countries towards the secondary and tertiary sectors. Such shifts happened in the past in the EU and other HI countries, partly due to the relocation of material production abroad from developed to emerging countries. At a global level, we assume that such a shift is not possible, and the primary products needed for an expanding economy have to be made somewhere. Visions of re-industrializing Europe, which entails 'bringing back' primary industries like mining and manufacturing to Europe (EC, 2013) are also not included in our scenarios, as the structure of the global economy is not actively adapted in this sense.
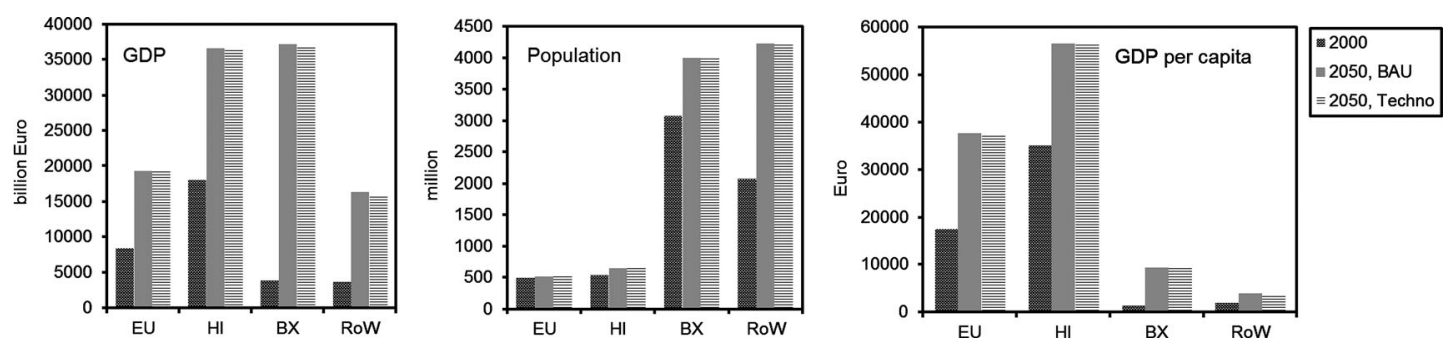

Figure 1 GDP, population, and GDP per capita in the BAU and TS 
Trade volumes tend to rise as a result of global specialization, economies of scale, and the reduction of trade barriers (Helpman \& Krugman, 1985; Hummels, Ishii, \& Yi, 2001). In recent decades this has led to high rates of growth in international trade, much higher than economic growth (Krugman, Cooper, \& Srinivasan, 1995). However, in the future it is likely that cost structures in different countries will become more similar as they approach similar levels of affluence (see Figure 1 for GDP per capita in our scenario), with reduced global income inequality (Chen \& Ravallion, 2004). Given that international trade barriers and international trade margins have already been reduced substantially, being a fraction of what they used to be (Krugman et al., 1995), we assume that trade volumes will not grow faster than GDP. Accordingly, we did not actively adapt the share of international trade flows in global GDP.

\subsubsection{Techno-scenario}

Next, specific $\mathrm{CO}_{2}$ emissions-reducing technologies are introduced on top of the BAU scenario, including a substantial shift to electricity use generated by fossil fuel power plants equipped with carbon capture and storage (CCS) and a substantial share of wind and solar. The chosen technologies include the large-scale technology developments that are feasible and could probably be implemented in the time frame up to 2050. These technologies do not include every emissionreduction technology that is available, but typically represent technologies that have proven themselves beyond the pilot scale. A detailed list of the technologies implemented in the Techno 2050 scenario in the transport sector, cement production, steel production, the built environment, private households, commercial energy use, and electricity supply sector is given in the supporting online information. Given the slow introduction of new (energy) technologies (Kramer \& Haigh, 2009), it is very doubtful that technologies that are not well known by now will make a large contribution to carbon emissions reductions by 2050. The scenarios assume a mix of low-carbon technologies for electricity generation rather than the implementation of a specific technology such as full electricity generation by bio-based solar cells. They also do not include potentially disruptive technology developments that do not yet exist, such as nuclear fusion. Even though these disruptive technologies may come into existence in the next few years, it is doubtful that, within the 30year time frame, they will substantially change the existing energy production and consumption system.

Shifts in primary energy for electricity production are substantial in our scenario (based on Jakeman \& Fisher, 2006), with a substantial increase in the share of other renewables, enhanced use of biomass, and a relatively constant share of nuclear (see Figure 2). The electricity supply mix could have been chosen such that renewables have a (much) higher share. However, based on the rates of penetration of new renewable technologies (Kramer \& Haigh, 2009), the long lifetime of the coal power plants that are being built today, and the shale gas revolution, it seems not unreasonable that even in 2050 fossil fuel-based electricity generation will still play a substantial role. The role of biomass for electricity generation grows fast compared to the starting situation, but in 2050 remains rather small (4.4 EJ or $2.7 \%$ of total electricity supply) in absolute terms compared to other models that implement a $2{ }^{\circ} \mathrm{C}$ scenarios (Rose et al., 2014). Our scenario choice is based on the strong indication that any increase in land for biomass leads to increased competition for land, which may induce substantial land-use change and conflict with biodiversity protection 

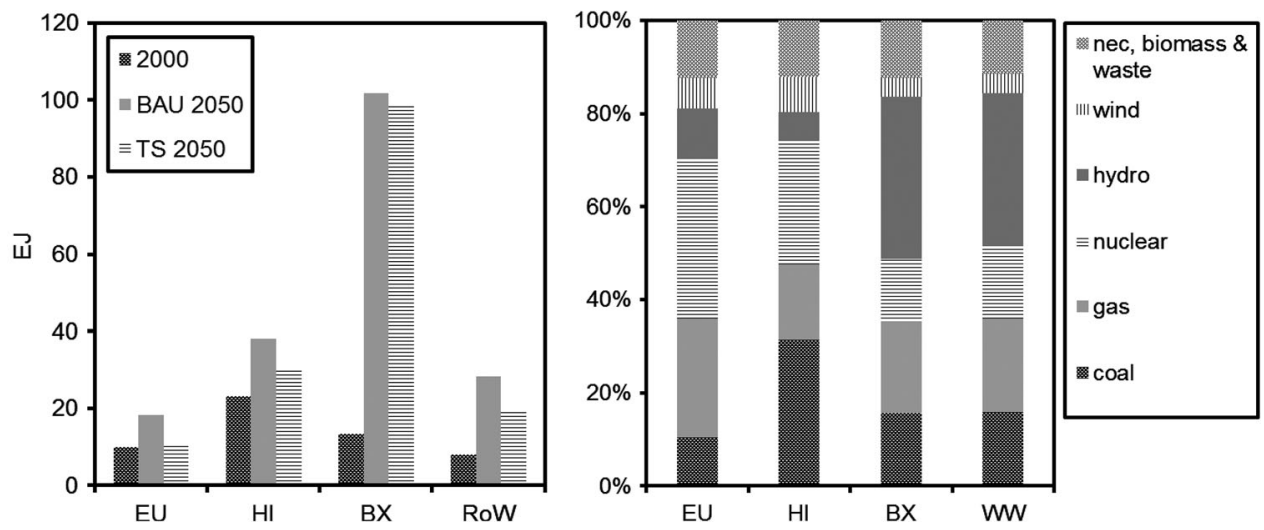

Figure 2 Total electricity supply in 2000, 2050 BAU, and 2050 TS (left) and the electricity supply mix in the 2050 TS (right)

and food supply. Even a modest use of biofuels in the US has been connected to accelerated clearing of the Brazilian rain forest (Fargione, Hill, Tilman, Polasky, \& Hawthorne, 2008; Searchinger et al., 2008). Although the shares of some electricity generation technologies stay the same (e.g. nuclear), it implies tremendous absolute growth compared to 2000, as electricity use expands so much (see Figure 2). In this technology-oriented step, energy-using industries adapt their source of energy in line with the overall assumptions on shifts in primary energy input.

Electricity production technologies change substantially. By 2050 all coal and gas-fired power stations (including those using biomass) are assumed to be equipped with CCS, reducing $\mathrm{CO}_{2}$ emissions from these power plants by $80 \%$. For that level of CCS, large-scale transport systems are probably required to bring the $\mathrm{CO}_{2}$ from the major sources of incineration to large saline aquifers. Such details have been taken into account using average additional material and energy requirements based on NETL (2010).

In households, the built environment, service sectors, and cement and steel production, feasible and probable energy-saving measures are implemented. A detailed overview of these measures is given in the supporting online information. Technology development in the steel sector was based on EPA (2012). Technological improvements in the cement production sector were taken from EPA (2010) and Worrell, Martin, and Price (2000). Passenger road transport was assumed to be based mostly on battery-electric or plugin-hybrid cars with vehicle efficiencies based on Girod et al. (2012) and van Vliet, den Elzen, and van Vuuren (2009). Domestic and commercial energy consumption was based on information from EPA (2000), Daioglou, van Ruijven, and van Vuuren (2012), Isaac and Van Vuuren (2009), and DECC (2013). These general technology developments are quite substantial in their emissions reductions and cover around 30 of the 129 sectors distinguished in EXIOBASE. In the present scenario, the cement production sector reduces $\mathrm{CO}_{2}$ emissions by $3 \%$, whereas the iron and steel production sector uses $6 \%$ less coal and about $50 \%$ less natural gas. Water transport and aviation technologies do not change other than the improved efficiency that was already part of the BAU scenario. 


\subsubsection{Towards-2-degrees scenario}

After implementing all main feasible and probable technological solutions for climate change emission mitigation as reflected by the TS scenario, behavioural changes by consumers remain an option for further emissions reduction. Two types of behavioural changes have been investigated:

- A shift from the consumption of high carbon-intensive products (goods and services) like air travel to low carbon-intensive products, like music performance and theatre.

- Reduced production and consumption, implying reduced economic growth.

In this 2DS, on top of the TS we initially tried to adapt only the final demand structure to achieve the $2{ }^{\circ} \mathrm{C}$ emission reduction goal. Demand shifts had to be so extreme that we chose to investigate more realistic changes to final consumption. As these would lead to a scenario falling short of the $2^{\circ} \mathrm{C}$ target, reduced economic growth was also assumed. Clearly, such measures are far from plausible in terms of psychology and policy instrumentation, but this demand shift gives insights into what the effects could be.

\subsection{Scenario model}

Manipulating the SUTs has been carried out using a set of Octave scripts (Eaton, Bateman, Hauberg, \& Wehbring, 2011). The basis of the scripts consists of about 30 smaller functions that carry out a specific task on the supply-use framework: e.g. checking the balance of the table, calculating efficiency, removing or inserting rows. These small functions have all been tested in an automated testing procedure. The smaller functions were used to set up the scripts that implemented one of the scenario assumptions. The main script was a sequence of all these scenario scripts plus some intermediate result logging. The complete scenario model is available in a software repository. ${ }^{3}$ See the supporting online information for a detailed description of the contents of the software repository.

A basic feature of the scripts and hence the model is the absence of dynamic mechanisms other than the exogenously defined changes discussed as part of the scenarios. These would include market mechanisms, which would change relative prices; the scenarios are in constant prices (year 2000) for all products. The conversion between monetary flows and physical flows is therefore straightforward. In the scenarios, new technologies are added in monetary terms, directly corresponding to their underlying physical composition and emission factors, at the given prices. These underlying physical specifications are not part of the SUT framework itself, but are modelled separately and fed into the SUT framework. There is no hybrid analysis in the sense of combining monetary and physical flow units, as all physical flows have been converted into monetary flows. Scenarios are translated into 'change factors'. An example of such a factor could be that the $\mathrm{CO}_{2}$ emission per unit of output of an industry sector will become a factor 0.45 of the original $\mathrm{CO}_{2}$ emission per unit output. Another example could be that the input of a certain product into an industry sector becomes 1.2 times the original input while everything else remains the same. These 'change factors' are multiplied with one or more of the relevant intermediate use, final use, or supply flows. When the commodity inputs or outputs of industry activities are changed, this creates an imbalance in the SUTs because the supply of commodities will not automatically match the use of those commodities. Depending on the scenario, this changed use of products may result in changed income and expenditure and/or changed commodity supply. After each scenario step the SUTs are rebalanced using a GRAS algorithm (Junius \& Oosterhaven, 2003).

For final analysis of the scenarios the SUTs were transformed into a product by product IOT based on the industry technology assumption (see, e.g., Eurostat (2008) for details). 


\section{Results and discussion}

\subsection{BAU and TS}

GHG emissions in the BAU scenario are $75 \mathrm{GtCO}_{2} /$ year in 2050 , which is over six times higher than the $11 \mathrm{GtCO}_{2}$ /year in 2050 corresponding to a $2{ }^{\circ} \mathrm{C}$ target (Vuuren et al., 2011). The $75 \mathrm{Gt}$ of $\mathrm{CO}_{2}$ already represents a substantial decoupling from GDP growth, but not yet absolute decoupling. A linear extrapolation of $\mathrm{CO}_{2}$ emissions on the basis of GDP growth alone would imply $129 \mathrm{GtCO}_{2}$ /year emissions in 2050. Because the BAU scenario is used as a reference on which $\mathrm{CO}_{2}$ emission mitigation assumptions are superimposed, the estimated $\mathrm{CO}_{2}$ emissions in the BAU scenario are a key starting point. High BAU $\mathrm{CO}_{2}$ emissions in 2050 would make reaching a $2{ }^{\circ} \mathrm{C}$ target more difficult. Our estimate is on the high end compared to the BAU scenarios by the OECD (2012a), which were calculated as $61 \mathrm{GtCO}_{2} /$ year in 2050 with the IMAGE/ENV Linkages model. The scenarios specified in our study use the same economic growth and population forecasts as specified in the OECD Environmental Outlook, so apparently factors like assumed autonomous energy-efficiency improvements cause this difference. An IPCC survey of $\mathrm{BAU}$ estimates of $\mathrm{CO}_{2}$ emissions in 2050 range from under $40 \mathrm{GtCO}_{2} /$ year to over $100 \mathrm{GtCO}_{2}$ /year (Meinshausen et al., 2011; Moss et al., 2010), implying that our BAU scenario is in the middle range. Our total $\mathrm{CO}_{2}$ emission estimate aligns with the IPCC RCP8.5 scenario (Riahi et al., 2011), which is also based on BAU assumptions (see Table 1). The distribution of emissions over the regions is, however, different. In our BAU scenario, fewer emissions will come from the RoW as in the IPCC RCP8.5 scenario.

The main results for the TS are given in Figure 3. This shows that the broad implementation of emissions-reducing measures, including $80 \%$ emissions reduction by CCS on the remaining coal and gas use, next to $80 \%$ emissions reduction by applying CCS to bioenergy, will lead to an absolute reduction in the emissions of developed countries (EU and $\mathrm{HI}$ ) by nearly 30\% relative to 2000. However, the sum of such measures is not enough to reduce emissions in the two developing world regions (BX and RoW) below the 2000 level. For the whole world, $\mathrm{CO}_{2}$ emissions increase from $26 \mathrm{Gt}$ to $39 \mathrm{Gt}$, more than three times the $2{ }^{\circ} \mathrm{C}$ target of $11 \mathrm{Gt}$ in 2050 . Special attention is merited regarding the role of the BX region (including China, India, Indonesia, and Brazil), responsible for more than half of all emissions in 2050. The emissions-reduction measures in the TS reduce

Table 1 Emissions of $\mathrm{CO}_{2}$ from fossil fuels and industry (in $\mathrm{GtCO}_{2}$ ), compared to RCP8.5, RCP4.5 and RCP2.6 scenarios (RCP database, 2009)

\begin{tabular}{|c|c|c|c|c|c|c|c|}
\hline Region & $\begin{array}{c}\text { Actual year } \\
2000\end{array}$ & $\begin{array}{c}\text { BAU scenario } \\
2050 \\
\end{array}$ & $\begin{array}{c}\text { Techno scenario } \\
2050\end{array}$ & $\begin{array}{l}\text { 2DS } 2050 \\
\text { reduced growth }\end{array}$ & $\begin{array}{c}\text { RCP8.5 } \\
2050\end{array}$ & $\begin{array}{c}\text { RCP4.5 } \\
2050 \\
\end{array}$ & $\begin{array}{c}\text { RCP2.6 } \\
2050 \\
\end{array}$ \\
\hline EU & 4.6 & 7.0 & 3.6 & 2.1 & 4.8 & 3.1 & 0.6 \\
\hline $\mathrm{HI}$ & 9.1 & 12.0 & 6.3 & 4.9 & 15.9 & 6.3 & 1.6 \\
\hline$B X$ & 8.6 & 45.8 & 23.7 & 4.4 & 34.6 & 18.0 & 4.7 \\
\hline Row & 3.9 & 10.0 & 5.7 & 3.6 & 17.9 & 13.1 & 4.3 \\
\hline Total & 26.2 & 74.8 & 39.3 & 15.0 & 73.2 & 40.5 & 11.1 \\
\hline
\end{tabular}




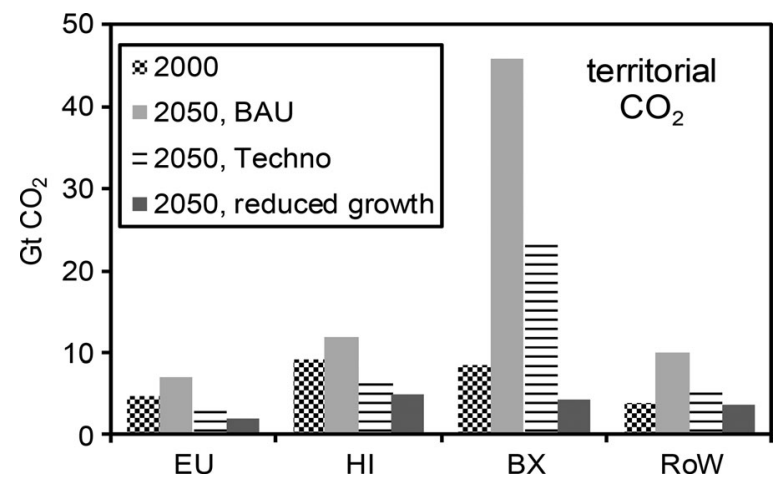

Figure 3 Territorial $\mathrm{CO}_{2}$ emissions in the different scenarios in the four regions compared with our 2DS scenario where GDP growth is assumed to be reduced

$\mathrm{CO}_{2}$ emissions by about 50\% compared to BAU in each region. Because the emission estimates in BAU 2050 for the BX countries are high compared to IPCC RCP scenarios, the contribution of BX in 2050 under the TS is also high. The total emissions in our TS in 2050 are very similar to the IPCC RCP4.5 emission scenario (Clarke et al., 2007; Thomson et al., 2011) for 2050, but the distribution between BX and RoW regions is quite different (see Table 1).

The emissions from aggregate sectors for the BAU and TS are shown in Figure 4. Most sectors and private and public consumers are able to reduce their $\mathrm{CO}_{2}$ emissions substantially in the TS compared to the BAU scenario. Agriculture shows a small increase in $\mathrm{CO}_{2}$ emissions because of the extra demand for bioenergy. The electricity supply sector reduces $\mathrm{CO}_{2}$ emissions from $24.5 \mathrm{GtCO}_{2}$ to $2.4 \mathrm{GtCO}_{2}$.

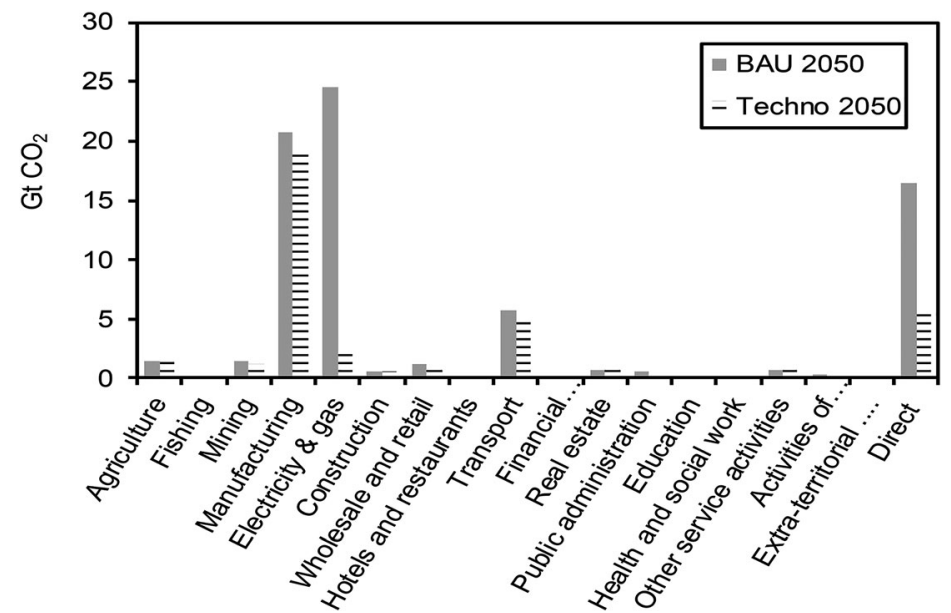

Figure 4 A breakdown of the TS GHG emissions into emissions per NACE level 1 industry category plus direct emissions from households (labelled 'Direct') 
Bioenergy in combination with CSS (BECCS) contributes $0.3 \mathrm{GtCO}_{2}$ to this emission reduction. The electricity supply sector has the largest share of total $\mathrm{CO}_{2}$ emissions (33\%) in the BAU scenario. In the TS it is reduced to $6 \%$. Having reduced the emissions from the electricity supply sector, the share of emissions from other sectors now becomes dominant, although emissions-reduction measures were also implemented in these sectors. Two aggregate sectors, manufacturing and transport, have a high share in the TS and show little improvement compared to BAU. This is the case even though in the manufacturing sector cement and basic steel production are assumed to have implemented $\mathrm{CO}_{2}$ emissions-reduction technologies and in the transport sector land transport is assumed to be mostly based on electricity.

For more insight into the origins of emissions, the manufacturing sector and transport sector have been further split up into the highest sector level detail available to see which industries contribute most to emissions in the TS (see Figure 5). In the manufacturing industries these are cement production and basic iron manufacturing (blast furnace works). Given that these two sectors already include the feasible and probable technological technologies for GHG emissions reduction until 2050, this means that further technologies would have to be developed and implemented substantially in the coming 35 years in order to further reduce emissions from these sectors. A plausible technology for cement manufacturing could be CCS for cement ovens (Schneider, Romer, Tschudin, \& Bolio, 2011). In iron and steel production, some CCS might be possible, especially when combining the first steps in reduction with coal gasification (Gielen, 2003). In the transport sector emissions are dominated by air transport and sea transport. No specific GHG emissions-reduction technologies were assumed to be implemented in these sectors, except general efficiency improvements. Further innovation in these sectors is necessary to bring down GHG emissions, for example by shifting to low-emission hydrogen or other low-emission energy carriers. Such speculative options have not been assumed in the TS.

\subsection{DS}

Taking the TS as starting point, a further option to reduce GHG emissions is the final demand shift from high carbon-intensive to low carbon-intensive products, including services. Quite extreme shifts
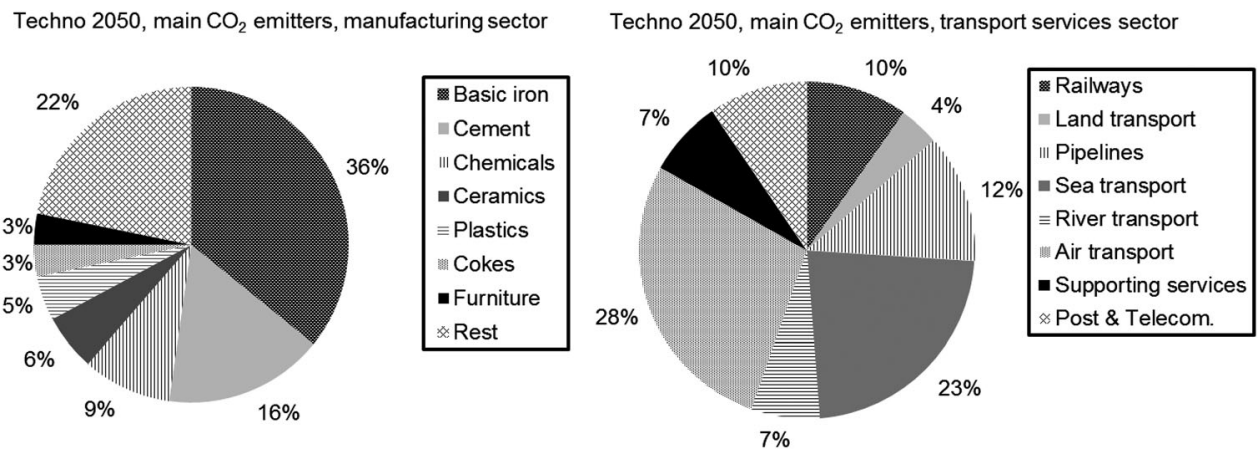

Figure 5 Main contributors to $\mathrm{CO}_{2}$ emissions in the manufacturing sectors and transport services sectors in the TS 
were investigated. The expenditure (including investments) on the most carbon-intensive products in the EU (responsible for $20 \%$ of total carbon emissions of the EU) was halved, redistributing this expenditure to all other lower carbon-intensive products bought by final consumers. This involves 50\% expenditure reduction on eight high-emission product groups (see Table 2). The products and data given are exemplary for the procedure only, indicating what such a shift might mean for emissions.

Only a modest reduction can be achieved by this measure - less than $10 \%$ emissions reduction from the $39.3 \mathrm{Gt}$ in the TS - so some $35 \mathrm{GtCO}_{2} /$ year would remain. Table 2 shows further that the $\mathrm{CO}_{2}$ emissions from aviation form one of the most important categories that should be reduced. It is, however, very unrealistic that the 50\% expenditure reduction assumed in our scenario could be realized. The income elasticity for demand for air transport is high - above 2 in developing countries and somewhat lower in developed countries (Smyth \& Pearce, 2008). Rising GDP and income will therefore lead to a relatively higher rise in demand for air transport. Extreme - and probably unrealistic - rises of the price of air transport would be required to make the 50\% demand reduction in our scenario reality. Hence, we separately investigated how much less the economy would have to grow in order to remain within the $2{ }^{\circ} \mathrm{C}$ target in comparison with the OECD projections in our original BAU scenario. In this lower growth scenario option we made the straightforward assumption that GDP growth is only a result of population growth and efficiency improvements. So, there is no autonomous GDP growth as has been assumed based on OECD projections in the original BAU and TS. Because efficiency improvements in the BX and RoW region are assumed to be about the same, but population growth in the RoW region is larger than in the BX region, GDP growth in the RoW region is larger (a factor of 2.8 compared to 2000) than economic growth in the BX region (a factor of 1.8).

This scenario has severe disadvantages, as inequality in GDP per capita between the four regions persists, and lower growth is not an aspiration in any region. This reduced-growth scenario is simply introduced as a thought experiment to examine how much reduced growth is actually necessary to stay within the $2{ }^{\circ} \mathrm{C}$ emission limits. The regional GDP levels for this reduced growth scenario are given in Table 3.

Table 2 The eight product groups whose production is responsible for about $20 \%$ of $\mathrm{CO}_{2}$ emissions in the $\mathrm{EU}$ in TS

\begin{tabular}{lc} 
Product groups & $\begin{array}{c}\text { Contribution to consumption-based } \mathrm{CO}_{2} \text { emissions } \\
\text { (\% of total EU consumption-based } \mathrm{CO}_{2} \text { emission) }\end{array}$ \\
\hline Ceramic goods & 0.4 \\
Electricity by coal & 0.6 \\
Sea and coastal water transportation services & 5.1 \\
Other petroleum products & 0.4 \\
Bricks, tiles and construction products, in baked clay & 0.5 \\
Basic iron and steel and ferro-alloys & 7.4 \\
Cement, lime and plaster & 2.8 \\
Air transport services & 5.3
\end{tabular}


Table 3 GDP, GDP growth (in trillion Euros), growth factor, and fraction of GDP relative to TS in the 2DS

\begin{tabular}{lccccc} 
Region & $\begin{array}{c}\text { GDP 2000 } \\
\text { (trillion Euro) }\end{array}$ & $\begin{array}{c}\text { GDP 2050 TS } \\
\text { (trillion Euro) }\end{array}$ & $\begin{array}{c}\text { 2050 2DS } \\
\text { (trillion Euro) }\end{array}$ & $\begin{array}{c}\text { Growth factor } \\
\text { relative to 2000 }\end{array}$ & $\begin{array}{c}\text { Fraction of GDP relative to GDP } \\
\text { forecasted in BAU and TS }\end{array}$ \\
\hline EU & 8.4 & 19.3 & 11.2 & 1.33 & 0.58 \\
HI & 18.1 & 36.6 & 27.5 & 1.52 & 0.75 \\
BX & 3.8 & 37.2 & 6.8 & 1.76 & 0.18 \\
RoW & 3.6 & 16.2 & 10.2 & 2.79 & 0.65 \\
Total & 34 & 109.3 & 55.7 & 1.64 & 0.52 \\
\hline
\end{tabular}

Compared to the original TS, GDP growth is halved on a world scale, but the growth reduction is unequal in the different regions of the world. For instance, the BX region will realize just $18 \%$ of the GDP calculated in the original TS. The $\mathrm{CO}_{2}$ emission level based on reduced economic growth and assumed implementation of all feasible and probable technological solutions from the original TS scenario comes quite close to the $2{ }^{\circ} \mathrm{C} \mathrm{CO}_{2}$ emission target for 2050 (see Table 1). However, the assumed growth reduction is particularly high. It is implausible that such a growth reduction will be realized by policy or free choice.

Although technologies and expenditures have been specified in detail, they should not be seen as predictions but only as technical options, required to give specificity in the scenarios. We have taken electric cars as the dominant drive mode, but it might as well be hydrogen or ammonia as a fuel, linked to an electric engine, or to other propulsion systems. It is the nature of the change that counts: a full shift in drive mode is required, away from decentralized carbon emissions. The technologies resulting will be efficient in some way, as costs are a main selection mechanism. So, our efficient electric cars are exemplary, not predictive for a specific technology. Any transport drive system should be (near) zero direct emission, as otherwise $\mathrm{CO}_{2}$ emissions from transport would remain too high. The other option, CCS on decentralized mobile emitters - although conceptually possible - seems hardly feasible. Also, biomass fuel for transport would be undesirable as it has already been used for electricity generation in our scenarios.

One of the important limitations of the use of a static model is that it does not capture dynamic effects. The dynamic effects of climate policies, including market and income effects, technology development, learning curves, etc., will surely have consequences for emissions. The static model might therefore have too high emission estimates. However, we force our model to reproduce the reasonable assumptions on GDP growth from the OECD, which dictates the income effects. On the other hand, dynamic models might be overoptimistic in terms of technologies relative to our input-output model. The input-output model captures economy-wide chain effects at a detailed level, which are not usually captured in integrated assessment models or computable general equilibrium (CGE) models. These models somehow have to deal with mechanisms not well established for long-term developments, including the adoption of emissions-reducing technologies. It is not certain that our assumptions are so negative compared to those, as we assume very substantial generic efficiency improvements, a very substantial introduction of emissions-reducing technologies and technology shifts, and on top of that a full connection of all fossil and non-fossil energy sources to CCS. 
The TS is in the middle domain of the scenarios linked to a substantial warming by 2100 . The $2{ }^{\circ} \mathrm{C}$ scenario relates to the RCP2.6 scenario, an area where there are few scenarios studies available. Getting to a $2{ }^{\circ} \mathrm{C}$ target may involve not so plausible socio-economic scenarios. Getting there in terms of the input-output scenario presented here ultimately involves a drastic assumption: limiting economic growth by about 50\%. This is much higher than other studies have so far reported. Knopf et al. (2009) and Edenhofer et al. (2009) have, for example, reported a GDP decrease of between 2.5\% and $5 \%$ due to climate policy measures. Such minor reductions relate more to the cost of climate policy than to an active reduction of economic growth as a means for emission reduction.

One of the essential assumptions underlying the different 2-degree scenario outcomes is the elaboration of the shift from the primary to the secondary and tertiary sectors. We assume that at a global level such a shift is not possible due to the still limited development stage of developing countries in 2050. Several integrated assessment models implicitly assume a development in industrial energy intensity similar to historic trends in developed countries through energy intensity curves. Without suggesting a preference for any type of modelling, this study shows that the difference in outcomes of climate policy cost predictions, emerging from such implicit modelling assumptions, may be very large.

\subsection{Base year, aggregation, and uncertainty}

The SUTs used in this study were derived from EXIOBASE and are a snapshot of the structural economy in 2000. Other multi-regional input-output models covering more recent years (even as recent as 2011) are available, e.g. GTAP (Hertwich \& Peters, 2009), WIOD (Dietzenbacher, Los, Stehrer, Timmer, \& de Vries, 2013), and Eora (Lenzen, Morgan, Kanemoto, \& Geschke, 2013). Taking a more recent SUT for the start of our analysis would probably improve the analysis of the emissions reductions achieved with feasible and probable technological measures until the year 2050, because there is one decade less of projections to be made. However, WIOD, GTAP, and Eora do not allow the same manipulations at the level of detail we can do in EXIOBASE. The WIOD and GTAP models have a much less detailed industry sector/product classification, and Eora has a mixed industry classification that in most countries is much more aggregated than in EXIOBASE. For our approach it is essential that we have a common and as detailed as possible description of technology in all regions in our SUTs, because the technology description is the handle by which we manipulate the SUTs. The higher the industry sector resolution, the more accurate we can be. Even with the 129-sector level of detail, we found that some sectors are still too aggregated to be able to easily implement the 2050 changes in the sector. Using the second version of EXIOBASE, which discerns 163 industry sectors and covers the year 2007, would be helpful in this respect. It is the combination of having detailed SUTs for each country/region and having a very large number of extensions compared to Eora, WIOD, and GTAP (Tukker \& Dietzenbacher, 2013) that makes EXIOBASE lag more in time than the other multi-regional input-output systems (MRIO) systems.

The level of aggregation in IOTs has an influence on the calculated emissions embodied in trade (Lenzen, 2011; Su \& Ang, 2010; Su, Huang, Ang, \& Zhou, 2010). Furthermore, the choice of using a multiregional model instead of a unidirectional or domestic technology assumption to calculate the emissions embodied in trade has an influence on the calculated emissions. In our approach, multidirectional trade is used to calculate the emissions embodied in trade, which is generally better than any other method (Andrew, Peters, \& Lennox, 2009). Choosing the highest sector resolution is the preferred approach when calculating emissions embodied in trade (Su et al., 2010) and is essential 
for implementing the technical changes. Our choice to model at an aggregated four-region level has been a pragmatic choice. These four regions were chosen to reflect the focus of this study (i.e. the EU) and describing its trade relations in a proper way. Given these four regions, two approaches could have been followed: (1) first aggregating the tables and then implementing the scenarios, (2) keeping the country detail and only aggregating the final results. This study follows option (1), because not enough data were available to specify the scenarios at the level of detail of the individual countries, and manipulating the SUTs would be much more cumbersome as the size of the system would be 100 times larger. The research by Su and Ang (2010) indicates that the level of spatial aggregation within China affects the calculated emissions embodied in its export. Going from one region to eight regions, the emissions embodied in China's export dropped 15\%. Because we do not focus on emissions embodied in trade alone, but on global emissions, the effect on calculated consumptionbased emissions will be smaller than this $15 \%$ and does not affect our conclusions.

\section{Conclusions and outlook}

The main conclusion is that reaching a $2{ }^{\circ} \mathrm{C}$ target is not possible with deep changes in technology alone. Deep changes in consumption patterns will only have limited effects too. Only technological solutions combined with behavioural changes and a 50\% reduction in economic growth may bring us close to the $2{ }^{\circ} \mathrm{C}$ goal. This scenario is politically unattractive, but can only be avoided by additional, innovative technical and behavioural change. Such technical and behavioural innovations would take time for their substantial introduction, probably having their effects after 2050 only. Furthermore, the current focus on emissions reduction in the electricity supply sector will mean that by 2050 other sectors become the major contributors to $\mathrm{CO}_{2}$ emissions, particularly steel and cement production, and air and sea transport services. Advanced measures to reduce $\mathrm{CO}_{2}$ emissions from these sectors should already be under development, as otherwise they have a high contribution to global $\mathrm{CO}_{2}$ emissions in 2050. Our study further makes it clear that policy efforts in the EU would by 2050 no longer have a substantial influence on global emissions. The share of EU emissions in effective scenarios is down to $7 \%$ as a result of economic growth in developing countries.

The technology development needed in the next few decades to achieve the goal of maximizing the temperature rise at $2{ }^{\circ} \mathrm{C}$ will require substantial public action in research and also the development of high-risk technologies. Furthermore, infrastructure development is a core public responsibility. If there are situations where emissions-reduction options are difficult to achieve due to a particular technology lock-in, specific measures have to be taken to resolve the problem. Missing and distorted markets are to be replaced or repaired. How exactly this is to be achieved, and with which set of instruments, does not follow from this scenario analysis. This analysis shows, however, that there is a dramatic task ahead for global and regional climate policy, with high demands on very broadly working climate policy instruments.

\section{Acknowledgements}

We thank three anonymous reviewers for their comments and suggestions, which greatly improved this manuscript. This work was supported by EU grant agreement no. 308680.under the FP7 call 
ENV.2012.6.1-4: Exploiting the full potential of economic instruments to achieve the EU's key greenhouse gas emissions reductions targets for 2020 and 2050.

\section{Notes}

1. As the study started before Croatia joined the EU, the EU is defined here as the EU27.

2. South Africa is part of the BRICs while all other African countries are part of the RoW.

3. The software repository can be found at the website of Leiden University (http://cml.leiden.edu/research/ industrialecology/researchprojects/projects/cecilia.html).

\section{References}

Andrew, R., Peters, G. P., \& Lennox, J. (2009). Approximation and regional aggregation in multi-regional inputoutput analysis for national carbon footprint accounting. Economic Systems Research, 21, 311-335. doi:10. 1080/09535310903541751

Bouwmeester, M. C. (2014). Economics and environment - Modelling global linkages (PhD thesis). University of Groningen, Groningen. ISBN 978-90367-7076-7. Retrieved from http://irs.ub.rug.nl/ppn/376969830

Cantono, S., Heijungs, R., \& Kleijn, R. (2008). Environmental accounting of eco-innovations through environmental input-output analysis: The case of hydrogen and fuel cell buses. Economic Systems Research, 20, 303-318. doi:10.1080/09535310802346351

Chen, S., \& Ravallion, W. (2004). How have the world's poorest fared since the early 1980s? The World Bank Research Observer, 19, 141-169. doi:10.1093/wbro/lkh020

Clarke, L., Edmonds, J., Jacoby, H., Pitcher, H., Reilly, J., \& Richels, R. (2007). Scenarios of greenhouse gas emissions and atmospheric concentrations (Sub-report 2.1A of Synthesis and Assessment Product 2.1 by the U.S. Climate Change Science Program and the Subcommittee on Global Change Research). Washington, DC: Department of Energy, Office of Biological \& Environmental Research.

Daioglou, V., van Ruijven, B. J., \& van Vuuren, D. P. (2012). Model projections for household energy use in developing countries. Energy, 37, 601-615. doi:10.1016/j.energy.2011.10.044

DECC. (2013). Energy consumption in the United Kingdom. Department of Energy \& Climate Change. Retrieved from https://www.gov.uk/government/collection/energy-consumption-in-the-uk

Dietzenbacher, E., Los, B., Stehrer, R., Timmer, M., \& de Vries, G. (2013). The construction of world input-output tables in the WIOD project. Economic Systems Research, 25, 71-98. doi:10.1080/09535314.2012.761180

Duchin, F. (1998). Structural economics: Measuring change in technology, lifestyles, and the environment. The Center for Resource Economics. Washington, DC: Island Press. ISBN 1-55963-606-8

Eaton, J. W., Bateman, D., Hauberg, S., \& Wehbring, R. (2011). GNU Octave, a high-level interactive language for numerical computations (Edition 3 for Octave version 3.8.0). Retrieved from www.gnu.org/software/octave/

EC. (2013). European competitiveness report 2013 - Towards knowledge driven reindustrialisation. Luxembourg: Publications Office of the European Union.

Edenhofer, O., Carraro, C., Hourcade, J.-C., Neuhoff, K., Luderer, G., Flachsland, C., ... Türk, A. (2009). The economics of decarbonization (Report of the RECIPE Project). Potsdam: Potsdam Institute for Climate Impact Research.

EPA. (2000). Energy cost and IAQ performance of ventilation systems and controls. Washington: Office of Air and Radiation, U.S. Environmental Protection Agency.

EPA. (2010). Available and emerging technologies for reducing greenhouse gas emissions from the Portland cement industry. Triangle Park, North Carolina: Office of Air Quality Planning and Standards, U.S. Environmental Protection Agency, Research. 
EPA. (2012). Available and emerging technologies for reducing greenhouse gas emissions from the iron and steel industry. Research Triangle Park, North Carolina: Office of Air Quality Planning and Standards, U.S. Environmental Protection Agency.

Eurostat. (2008). Eurostat manual of supply, use and input-output tables. Luxembourg: Office for Official Publications of the European communities. ISBN 978-92-79-04735-0, ISSN 1977-0375.

Fargione, J., Hill, J., Tilman, D., Polasky, S., \& Hawthorne, P. (2008). Land clearing and the biofuel carbon debt. Science, 319, 1235-1238. doi:10.1126/science.1152747

Gielen, D. (2003). $\mathrm{CO}_{2}$ removal in the iron and steel industry. Energy Conversion and Management, 44, 1027-1037. doi:10.1016/S0196-8904(02)00111-5

Girod, B., van Vuuren, D. P., \& Deetman, S. (2012). Global travel within the $2{ }^{\circ} \mathrm{C}$ climate target. Energy Policy, 45, 152-166. doi:10.1016/j.enpol.2012.02.008

Helpman, E., \& Krugman, P. R. (1985). Market structure and foreign trade. Increasing returns, imperfect competition, and the international economy. Cambridge, MA: MIT Press.

Hertwich, E. G., \& Peters, G. P. (2009). Carbon footprint of nations: A global, trade-linked analysis. Environmental Science \& Technology, 43, 6414-6420. doi:10.1021/es803496a

Hummels, D., Ishii, J., \& Yi, K.-M. (2001). The nature and growth of vertical specialization in world trade. Journal of International Economics, 54, 75-96. doi:10.1016/S0022-1996(00)00093-3

IPCC. (2014). Climate change 2014: Mitigation of climate change - IPCC Working Group III Contribution to AR5. Cambridge: Cambridge University Press.

Isaac, M., \& van Vuuren, D. P. (2009). Modeling global residential sector energy demand for heating and air conditioning in the context of climate change. Energy Policy, 37, 507-521. doi:10.1016/j.enpol.2008.09.051

Jakeman, G., \& Fisher, B. S. (2006). Benefits of multi-gas mitigation: An application of the global trade and environment model (GTEM). The Energy Journal, Multi-Greenhouse Gas Mitigation and Climate Policy, Special Issue.

Junius, T., \& Oosterhaven, J. (2003). The solution of updating or regionalizing a matrix with both positive and negative entries. Economic Systems Research, 15, 87-96. doi:10.1080/0953531032000056954

Knopf, B., Edenhofer, O., Barker, T., Bauer, N., Baumstark, L., Chateau, B., ... van Vuuren, D. (2009). The economics of low stabilisation: Implications for technological change and policy. In M. Hulme and H. Neufeldt (Eds.) Making climate change work for us (Chapter 11). Cambridge: Cambridge University Press.

Kramer, G. J., \& Haigh, M. (2009). No quick switch to low-carbon energy. Nature, 462, 568-569. doi:10.1038/ $462568 \mathrm{a}$

Krugman, P., Cooper, R. N., \& Srinivasan, T. N. (1995). Growing world trade: Causes and consequences. Brookings Papers on Economic Activity, 1995, 327-377. Retrieved from http://www.jstor.org/stable/2534577

Lahr, M. L., \& De Mesnard, L. (2004). Biproportional techniques in input-output analysis: Updating and structural analysis. Economic Systems Research, 16, 115-134. doi:10.1080/0953531042000219259

Lenzen, M. (2011). Aggregation versus disaggregation in input-output analysis of the environment. Economic Systems Research, 23, 73-89. doi:10.1080/09535314.2010.548793

Lenzen, M., Morgan, D., Kanemoto, K., \& Geschke, A. (2013). Building Eora: A global multi-region input-output database at high country and sector resolution. Economic Systems Research, 25, 20-49. doi:10.1080/09535314. 2013.769938

Meinshausen, M., Smith, S. J., Calvin, K., Daniel, J. S., Kainuma, M. L. T., Lamarque, J.-F., ... van Vuuren, D. P. (2011). The RCP GHG concentrations and their extension from 1765 to 2300. Climatic Change, 109, 213-241. doi:10.1007/s10584-011-0156-Z

Miller, R. E., \& Blair, P. D. (2009). Input-output analysis. Foundations and extensions (2nd ed.). Cambridge: Cambridge University Press.

Moss, R. H., Edmonds, J. A., Hibbard, K. A., Manning, M. R., Rose, S. K., van Vuuren, D. P., .. Wilbanks, T. J. (2010). The next generation of scenarios for climate change research and assessment. Nature, 463, 747-756. doi:10. 1038/nature08823 
NETL. (2010). Cost and performance baseline for fossil energy plants volume 1: Bituminous coal and natural gas to electricity report of the national energy technology laboratory. Pittsburgh, PA: U.S. Department of Energy, National Energy Technology Laboratory.

OECD. (2012a). OECD environmental outlook to 2050: The consequences of inaction. Paris: OECD Publishing.

OECD. (2012b). Looking to 2060: A global vision of long-term growth (OECD Economics Department Policy Notes, No. 15 November 2012). Paris: OECD Publishing.

RCP database. (2009). RCP database (Version 2.0.5) downloaded 2013-09-23. Retrieved from http://www.iiasa.ac.at/ web-apps/tnt/RcpDb

Riahi, K., Rao, S., Volker, K., Cho, C., Chirkov, V., Fischer, G., ... Rafaj, P. (2011). RCP8.5 - A scenario of comparatively high greenhouse gas emissions. Climate Change, 109, 33-57. doi:10.1007/s10584-011-0149-y

Rose, S. K., Kriegler, E., Bibas, R., Calvin, K., Popp, D., van Vuuren, D., \& Weyant, J. (2014). Bioenergy in energy transformation and climate management. Climate Change, 123, 477-493. doi:10.1007/s10584-013-0965-3

Schneider, M., Romer, M., Tschudin, M., \& Bolio, H. (2011). Sustainable cement production - present and future. Cement and Concrete Research, 41, 642-650. doi:10.1016/j.cemconres.2011.03.019

Searchinger, T., Heimlich, R., Houghton, R. A., Dong, F., Elobeid, A., Fabiosa, J., ... Yu, T.-H. (2008). Use of U.S. croplands for biofuels increases greenhouse gases through emissions from land-use changes. Science, 319, 12381240. doi:10.1126/science.1151861

Smyth, M., \& Pearce, B. (2008, April). Air travel demand (IATA Economics Briefing No 9). IATA.

Stone, R. (1961). Input-output and national accounts. Paris: Office of European Economic Cooperation.

$\mathrm{Su}, \mathrm{B} .$, \& Ang, B. W. (2010). Input-output analysis of $\mathrm{CO}_{2}$ emissions embodied in trade: The effects of spatial aggregation. Ecological Economics, 70, 10-18. doi:10.1016/j.ecolecon.2010.08.016

$\mathrm{Su}$, B., Huang, H. C., Ang, B. W., \& Zhou, P. (2010). Input-output analysis of $\mathrm{CO}_{2}$ emissions embodied in trade: The effects of sector aggregation. Energy Economics, 32, 166-175. doi:10.1016/j.eneco.2009.07.010

Thomson, A. M., Calvin, K. V., Smith, S. J., Kyle, G. P., Volke, A., Patel, P., .. Edmonds, J. A. (2011). RCP4.5: A pathway for stabilization of radiative forcing by 2100. Climate Change, 109, 77-94. doi:10.1007/s10584-011-0151-4

Timmer, M. P. (Ed.). (2012). The world input-output database (WIOD): Contents, sources and methods (WIOD Working Paper No. 10). Groningen: University of Groningen.

Tukker, A., Bulavskaya, T., Giljum, S., de Koning, A., Lutter, S., Simas, M., .. Wood, R. (2014). The global resource footprint of nations; carbon, water, land and materials embodied in trade and final consumption calculated with EXIOBASE 2.1. Leiden/Delft/Vienna: Trondheim.

Tukker, A., \& Dietzenbacher, E. (2013). Global multiregional input-output frameworks: An introduction and outlook. Economic Systems Research, 25, 1-19. doi:10.1080/09535314.2012.761179

Tukker, A., Goldbohm, R. A., de Koning, A., Verheijden, M., Kleijn, R., Wolf, O., ... Rueda-Cantuche, J. M. (2011). Environmental impacts of changes to healthier diets in Europe. Ecological Economics, 70, 1776-1788. doi:10. 1016/j.ecolecon.2011.05.001

Tukker, A., de Koning, A., Wood, R., Hawkins, T., Lutter, S., Acosta, J., ... Kuenen, J. (2013). Exiopol - development and illustrative analyses of a detailed global MR EE SUT/IOT. Economic Systems Research, 25, 50-70. doi:10.1080/ 09535314.2012 .761952

UNFCCC. (2011). Report of the Conference of the Parties on its sixteenth session, held in Cancun from 29 November to 10 December 2010. Addendum; Part two: Action taken by the Conference of Parties at its sixteenth session (FCCC/CP/2010/ 7/Add.1). Geneva: United Nations Office at Geneva.

van Vliet, J., den Elzen, M. G. J., \& van Vuuren, D. P. (2009). Meeting radiative forcing targets under delayed participation. Energy Economics, 31, S152-S162. doi:10.1016/j.eneco.2009.06.010

Vuuren, D. P. van, Stehfest, E., den Elzen, M. G. J., Kram, T., van Vliet, J., Deetman, S., .. van Ruijven, B. (2011). RCP2.6: Exploring the possibility to keep global mean temperature increase below $2^{\circ} \mathrm{C}$. Climatic Change, 109 , 95-116. doi:10.1007/s10584-011-0152-3

Worrell, E., Martin, N., \& Price, L. (2000). Potentials for energy efficiency improvement in the US cement industry. Energy, 25, 1189-1214. doi:10.1016/S0360-5442(00)00042-6 